\title{
УСЛОВИЯ И ОСОБЕННОСТИ ФОРМИРОВАНИЯ МЕТАБАЗИТОВЫХ ПОРОД ТЕЛЕЦКОЙ ЗОНЫ ГОРНОГО АЛТАЯ
}

Зиндобрый Виктор Дмитриевич

Студент

ФГБОУ ВПО «Санкт-Петербургский государственный университет»

Буслов Михаил Михайлович д.г.-м.н., главный научный сотрудник ФГБУ «Институт геологии и минералогии им. В.С. Соболева СО РАН»

\begin{abstract}
Аннотация: в работе приведены данные петрографических, геохимических и минералогических исследований метабазитовых и метатерригенных пород Телецкой зоны Горного Алтая. Показано, что метабазиты по геохимическому составу отвечают океаническим базальтам (E-MORB, OIB, OPB), метатерригенные породы - известково-щелочным андезибазальтам и андезитам островных дуг. Химический анализ амфиболов из метабазитов показал, что амфиболы относятся к кальциевым и являются зональными: составы кристаллов варьируют от тремолитов и низкощелочных роговых обманок (в центре) до высокощелочных роговых обманок и паргаситов (на периферии). Полученная совокупность данных позволяет считать, что исследуемые породы входят в состав аккреционного клина, в котором совмещены базальты океанической коры и турбидиты глубоководного желоба, образованные в результате разрушения пород островной дуги.
\end{abstract}

Ключевые слова: амфибол, базальт, метатерригенный сланец, Горный Алтай, геохимия

\section{CONDITIONS AND FEATURES OF THE FORMATION OF METABASITE ROCKS OF THE TELETSK ZONE OF GORNY ALTAI}

Zindobryi Viktor Dmitrievich Buslov Mikhail Mikhailovich 
Abstract: the paper presents the data of petrographic, geochemical and mineralogical studies of metabasite and metaterrigenous rocks of the Teletsk zone of Gorny Altai. It is shown that the material composition of metabasites belongs to basalts oceanic (E-MORB, OIB and OPB), metaterrigenous - calc-alkaline basaltic andesite and andesites of island arcs. Chemical analysis of amphiboles from metabasites showed that amphiboles belong to calcium and are zoned: crystal compositions vary from tremolites and low-alkaline hornblende (in the center) to high-alkaline hornblende and pargasites (on the periphery). The obtained set of data allows us to consider that the studied rocks are part of an accretionary wedge, in which oceanic basalts and turbidites of the deep-water trench, formed as a result of the destruction of rocks of the island arc.

Key words: amphibole, basalt, metaterrigenous schist, Gorny Altai, geochemistry

Горный Алтай как гетерогенное складчатое сооружение характеризуется полициклическим развитием. На его территории выделяются разновозрастные складчатые зоны с различным сочетанием осадочных, магматических и метаморфических комплексов и формаций. По времени проявления главной складчатости зоны подразделяются на салаирскую Бийско-Катунскую, каледонские Телецкую (Саянскую) и Холзунско-Чуйскую, герцинские Ануйско-Чуйскую и Уйменско-Лебедскую $[1,2,3]$.

В данной работе рассмотрены особенности вещественного состава метаморфизованных вулканитов Телецкой зоны смятия, расположенной в восточной части Горного Алтая и простирающейся более чем на 300 км, от Телецкого озера на севере до пос. Акташ на юге.

В строении восточной части Горного Алтая выделяется три крупных блока (террейна): Горно-Алтайский, Западно-Саянский и Телецкий, отделенные друг от друга крупными Северо-Саянской, Телецко-Башкаусской и Шапшальской сдвиговыми зонами $[4,5,6,7]$ (рис. 1). 


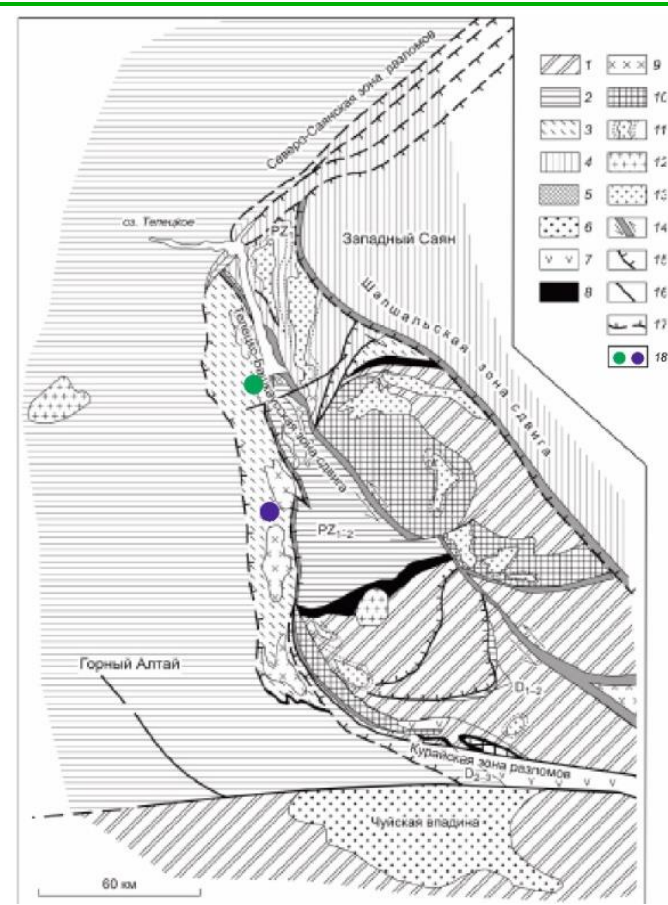

\section{Рис. 1. Структурная схема восточной части Горного Алтая [6]}

1 - Алтае-Монгольский террейн гондванской группы; 2-4 - террейны окраины Сибирского континента: 2 - Горно-Алтайский, 3 - Телецкий, 4 - Западно-Саянский; 5 - континентальная моласса, P; 6 - континентальная моласса, $\mathrm{J}_{1-2} ; 7$ - вулканогенноосадочные породы, D; 8 - Улаганский сегмент Чарышско-Теректинско-Улаганско-Саянской сутурно-сдвиговой зоны; 9 - гранитоиды, $\mathrm{PZ}_{2} ; 10$ - зональные метаморфические комплексы, $\mathrm{S}_{2}-\mathrm{D}_{1} ; 11$ - гранито-гнейсовые купола, $\mathrm{D}_{3}-\mathrm{C}_{1} ; 12$ - граниты, $\mathrm{T}_{1} ; 13$ - граниты, $\mathrm{D}_{3}-\mathrm{C}_{1}$; 14 - сдвиги, $\mathrm{D}_{3}-\mathrm{C}_{1} ; 15$ - надвиги, $\mathrm{D}_{3}-\mathrm{C}_{1} ; 16$ - сдвиги, $\mathrm{P}-\mathrm{T} ; 17$ - надвиги и сдвиго-надвиги, $\mathrm{C}_{3}-\mathrm{P}$; 18 - точки обора проб (зеленый кружок - № Б-19-701, синий кружок - № Б-17-121, Б-17-125, Б-17-126, Б-17-128, Б-17-129, Б-17-146, Б-17-149, Б-17-150)

Горно-Алтайский террейн представлен геодинамическими комплексами венд-раннекембрийской примитивной и развитой островных дуг, аккреционными комплексами, включающими турбидиты и океаническую кору, венд-кембрийскими кремнисто-терригенными породами преддугового прогиба, ородовикско-силурийским осадками пассивной окраины, а также девонскими образованиями развитой островной дуги [8].

Западно-Саянский террейн представлен позднесилурийскораннекарбоновыми зональными гранито-гнейсовыми куполами, сформированными преимущественно за счет кембрийских терригенных пород (турбидитов). Турбидиты содержат прослои туфов, а также обломки кремнистых пород и эффузивов различного состава. Среди турбидитов часто встречаются девонские дайки и массивы габброидов и риолитов, подверженные метаморфизму [4, 9]. 
Телецкий террейн (зона) представлен породами зеленосланцевой фации метаморфизма, прорванными крупным ранне-среднедевонским гранитоидными массивами. Вокруг массивов сформирована контактовая зона метаморфических пород, сложенная Qtz-Bt, Qtz-Bt-Ms, Qtz-Chl-Bt сланцами, двуслюдяными гнейсами и амфиболитами $[4,5]$.

В результате проведенных петрографических исследований пород из Телецкой зоны среди метаморфизованных вулканитов по минеральному составу и степени метаморфизма было выделено 2 типа пород:

1. Метабазальты, представленные Pl- и Pl-Amp порфиритами (рис. 2) и афировыми метабазальтами (рис. 3), метаморфизованными в условиях фации зеленых сланцев и сохранившими первичные магматические структуры;
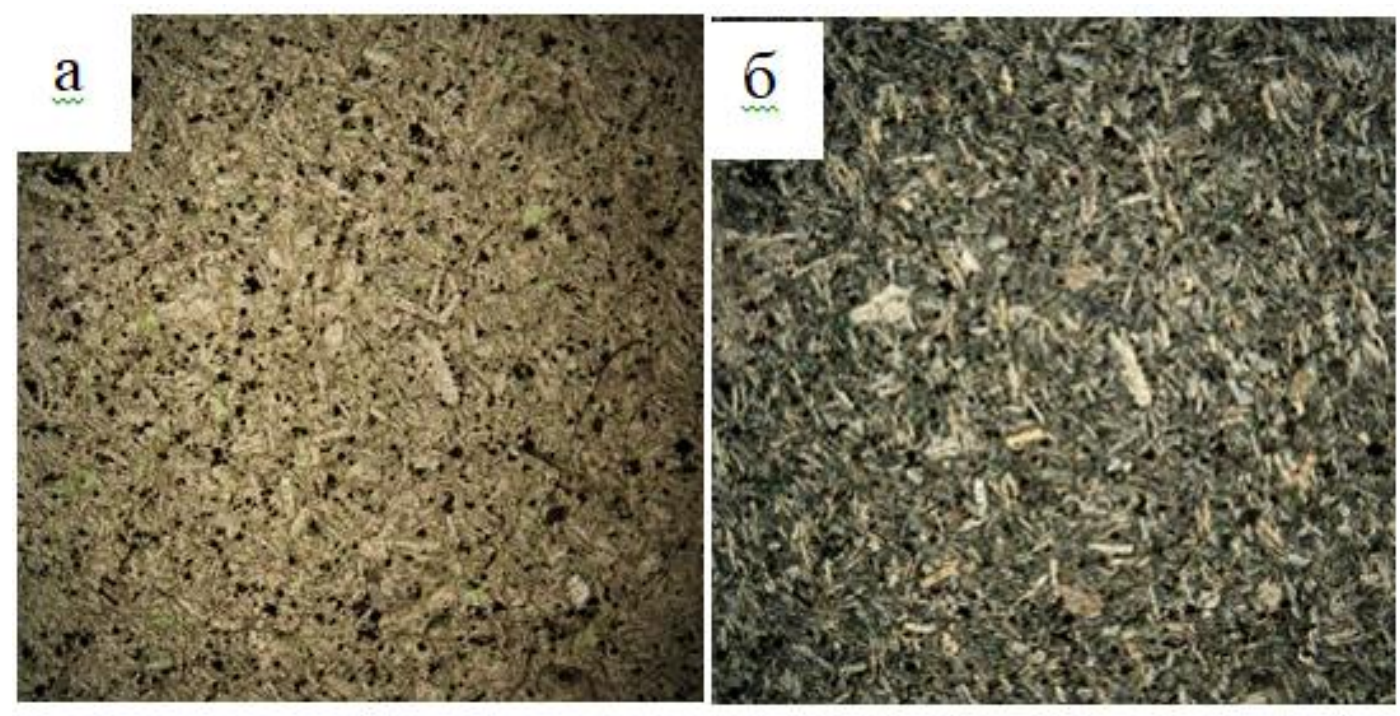

Рис. 2. Шлиф № Б-17-118. Pl-Amp порфирит

Минеральный состав: $\mathrm{Pl}+\mathrm{Chl}+\mathrm{Amp}$. Структура порфировая, текстура массивная $(\mathrm{a}-\mathrm{B}$ проходящем свете, б - в скрещенных николях). Поле зрения 7х9 мм

Афировые метабазальты, не имеющие ярко выраженных вкрапленников, содержат в своем составе кристаллы Amp, Ep, Chl, Pl и Qtz, и в большей степени, по сравнению с порфиритами, преобразованы в зеленосланцевой фации метаморфизма (рис. 3). 

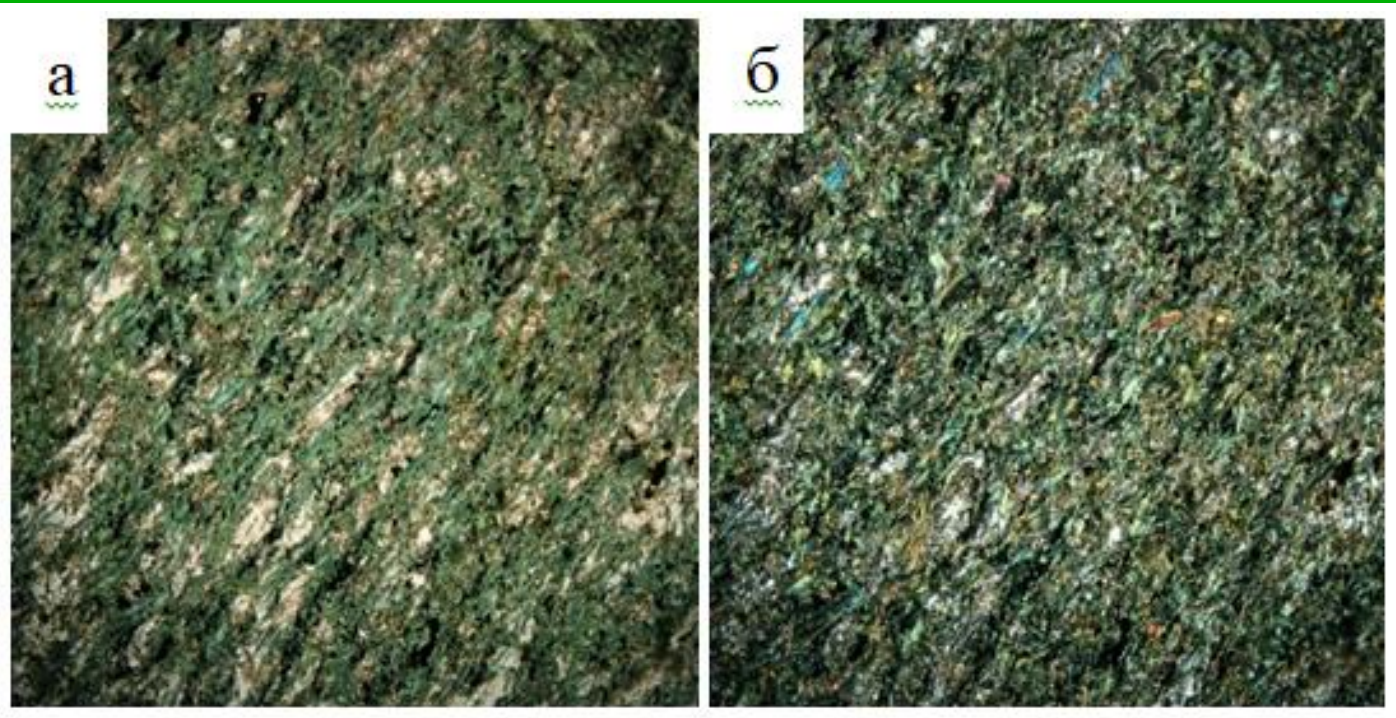

\section{Рис. 3. Шлиф № Б-17-128. Метабазальт}

Минеральный состав: Amp+Ep+Pl+Chl. Структура афировая, текстура массивная (a - в проходящем свете, б - в скрещенных николях). Поле зрения 7х9 мм

2. Метатерригенные сланцы имеют ясно выраженную полосчатость и представлены Qtz-Amp-Chl, Qtz-Amp-Ep и Qtz-Amp-Bt сланцами, образованные в условиях фации зеленых сланцев (рис. 4).
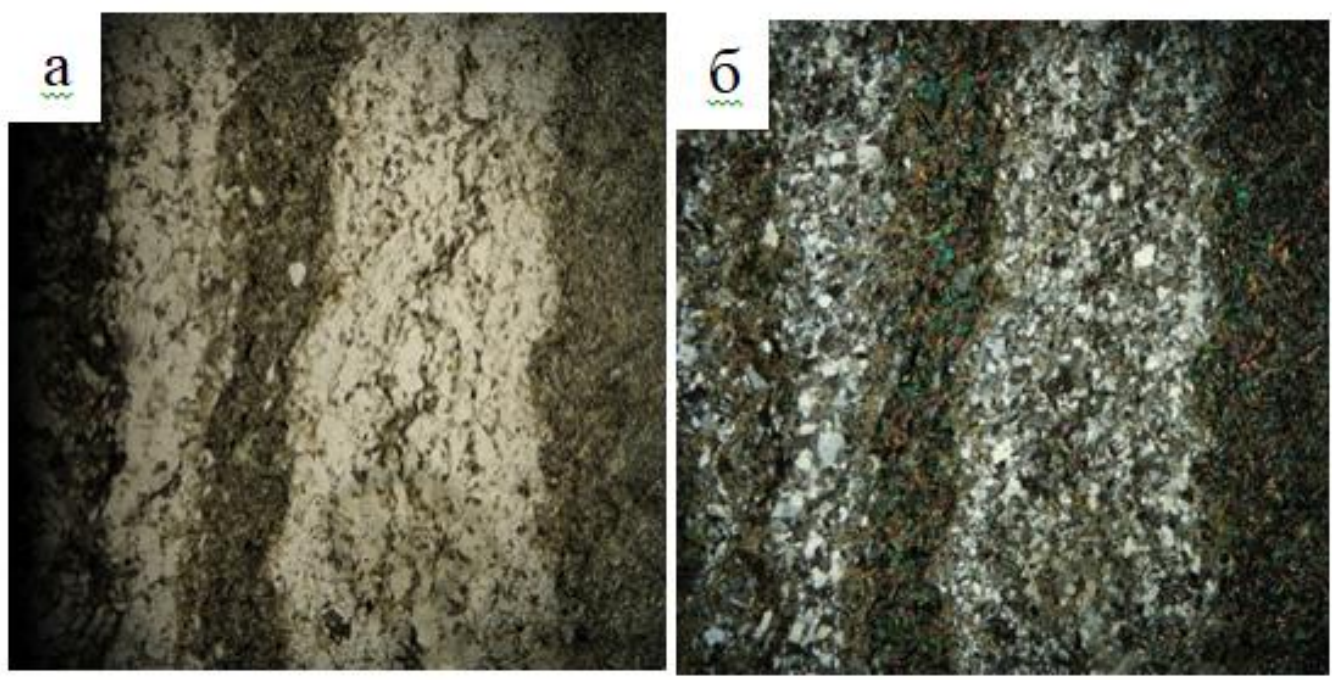

\section{Рис. 4. Шлиф № Б-17-144. Qtz-Ep-Bt сланец}

Минеральный состав: Qtz+Ep+Bt+Chl+Pl. Структура гранонематобластовая, текстура полосчатая ( $\mathrm{a}$ - в проходящем свете, б - в скрещенных николях). Поле зрения 7х9 мм

Петрохимические исследования показали, что на TAS-диаграмме [10] метатерригенные сланцы попадают в поля базальтов, андезибазальтов и андезитов, а метабазальты - в поле базальтов (Рис. 5 (a)). На тройной классификационной диаграмме $\mathrm{Al}_{2} \mathrm{O}_{3}-\mathrm{FeO}_{\mathrm{t}}+\mathrm{TiO}_{2}-\mathrm{MgO}$ [11] исследуемые породы попадают, в основном, в поля высокожелезистых и 
высокомагнезиальных толеитовых базальтов, однако также присутствуют породы, составы которых отвечают известково-щелочным базальтам (рис. 5 (б)).

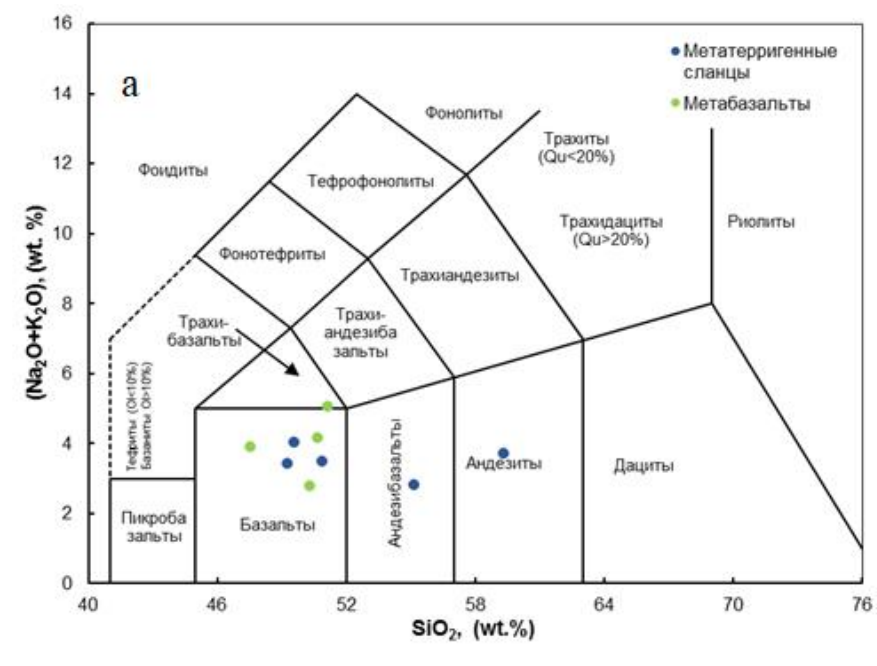

$$
\mathrm{Fe}^{\top}+\mathrm{Ti}
$$

$\sigma$

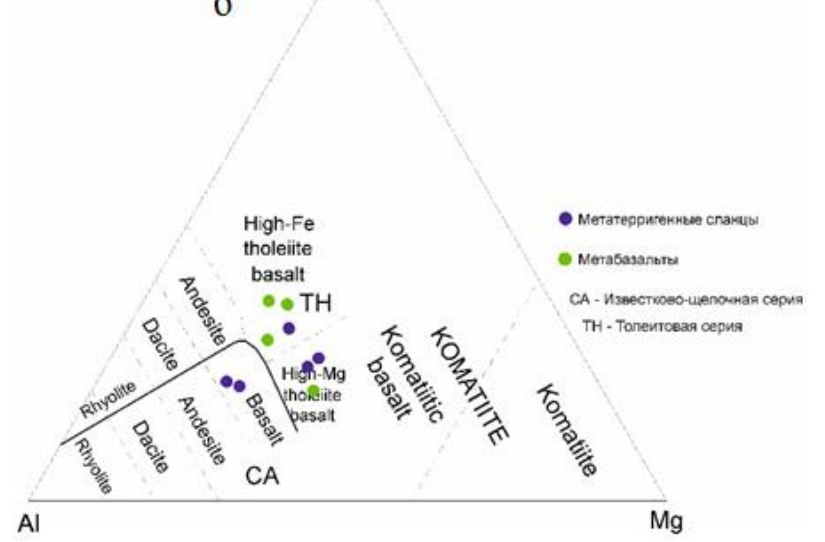

\section{Рис. 5. Петрохимические диаграммы для метабазальтов}

\section{и метатерригенных сланцев из Телецкой зоны}

a - TAS-диаграмма [10]; б - диаграмма $\mathrm{Al}-\left(\mathrm{Fe}_{\mathrm{t}}+\mathrm{Ti}\right)-\mathrm{Mg}$ [11]

По геохимическим показателям метатерригенные сланцы и метабазальты представлены несколькими типами протолитов.

Большинство графиков распределения редкоземельных элементов, нормированных по хондриту [12] для метабазальтов, сохранивших первичные структуры, и метатерригенных сланцев демонстрируют слабонаклонные спектры распределения REE, слегка обогащенные LREE относительно HREE $(\mathrm{La} / \mathrm{Yb})_{N}=2,40$ в среднем. На мультиэлементных диаграммах они также образуют слабо отрицательные спектры с различной степенью дифференциации $\mathrm{Rb}, \mathrm{Cs}, \mathrm{Ba}, \mathrm{Th}, \mathrm{K}$ : слабо выраженной у метабазальта и более отчетливой у метаморфических пород. Кроме того, в метабазальте проявлен Ті- 
минимум, а в метаморфических породах - Р-минимумы. Такие спектры характерны для океанических базальтов E-MORB типа (рис. 6).

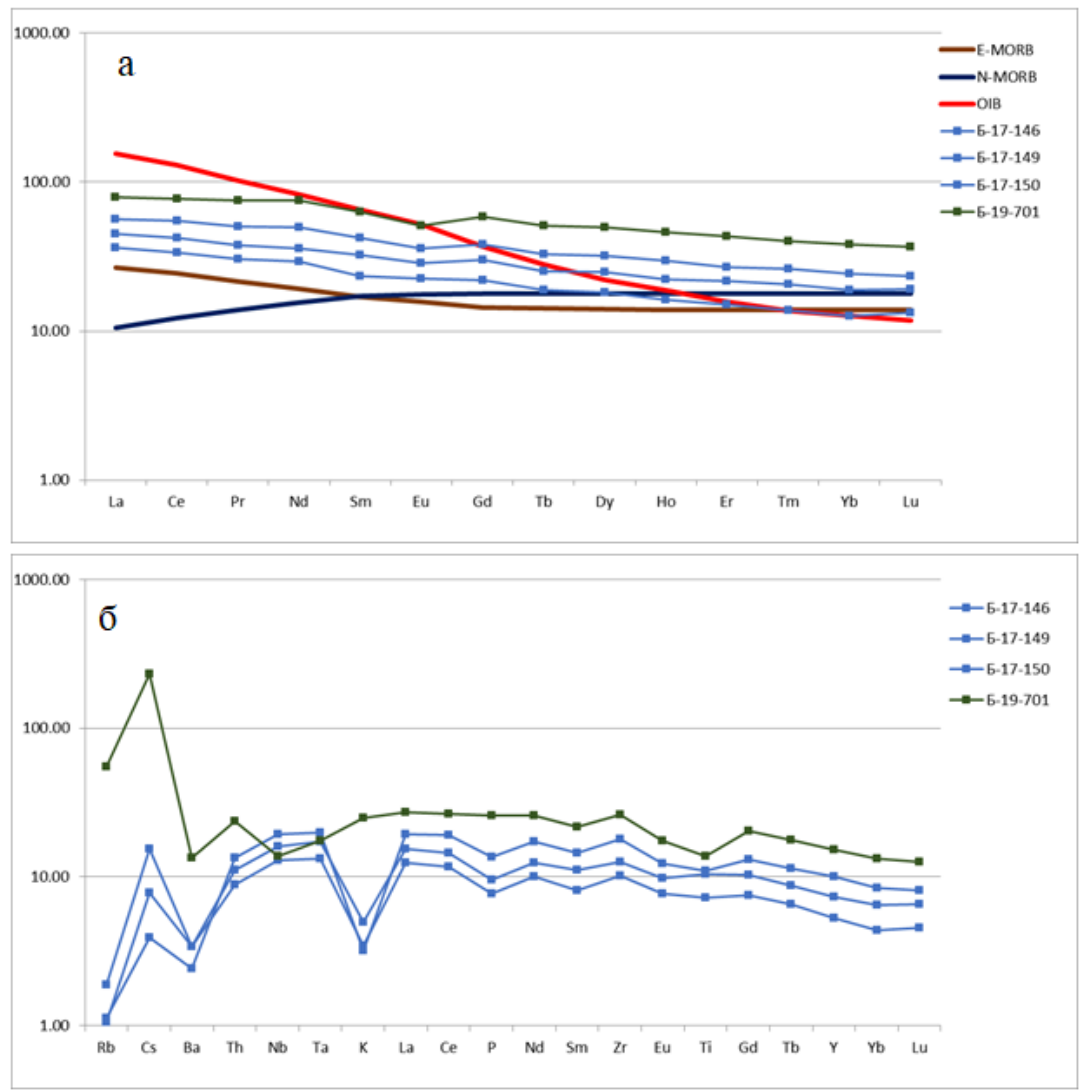

Рис. 6. Нормированные [12] по хондриту кривые распределения редкоземельных элементов (а) и нормированные по примитивной мантии мультиэлементные диаграммы редких элементов (б) для метабазальтов и метатерригенных сланцев из Телецкой зоны

Помимо базальтов срединно-океанических хребтов в Телецкой зоне встречаются метаморфические породы, протолитом для которых служили другие типы океанических базальтов. Один образец имеет спектры распределения редкоземельных элементов, близкие к ОІВ (метабазальт № Б-17-121) с $(\mathrm{La} / \mathrm{Yb})_{N}=7,42$, а второй - близкие к ОРВ (метабазальт № Б-17-128) с (La/Yb $)_{N}=1,57$. На мультиэлементной диаграмме метабазальт № Б-17-121 демонстрирует отчетливо проявленные К- и Р-минимумы, а наклон спектра, в целом, сильно отрицательный (рис. 7). Можно полагать, что протолитом для данного образца служили базальты океанических островов (OIB). Метабазальт № Б-17-128 на мультиэлементной диаграмме не имеет явно выраженных аномалий и наклона спектра в какую-либо сторону, поэтому, вероятно, протолитом для него служили базальты океанических плато (OPB). 

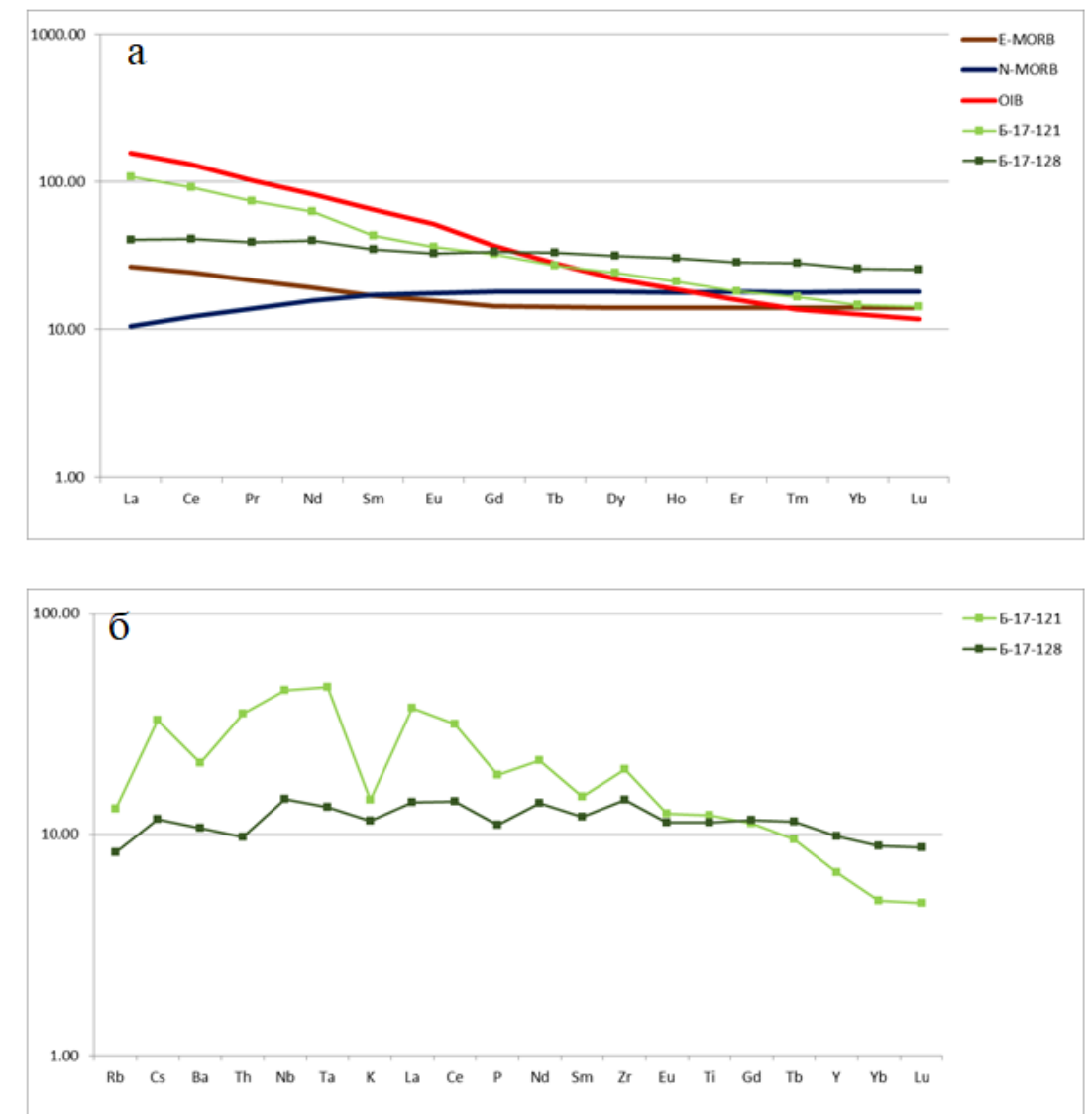

Рис. 7. Нормированные [12] по хондриту кривые распределения редкоземельных элементов (а) и нормированные по примитивной мантии мультиэлементные диаграммы редких элементов (б) для метабазальтов из Телецкой зоны

В качестве отдельной группы можно выделить метатерригенные сланцы, обладающие отрицательными спектрами распределения редкоземельных элементов с высокими отношениями LREE/HREE, близкими к OIB - $(\mathrm{La} / \mathrm{Yb})_{N}=6,33$ в среднем. Также у них наблюдается сильная отрицательная Еu-аномалии, свидетельствующая о фракционировании плагиоклаза. На мультиэлементных диаграммах изучаемые породы демонстрируют сильную дифференциацию $\mathrm{Rb}$, Cs, Ba, Th, K, повышенные значения отношения LILE/HREE и отчетливо выраженные Nb-Ta-, P- и Ti-минимумы. По этим данным можно предположить, что данные породы относятся к известково-щелочным островодужным базальтам (рис. 8). 

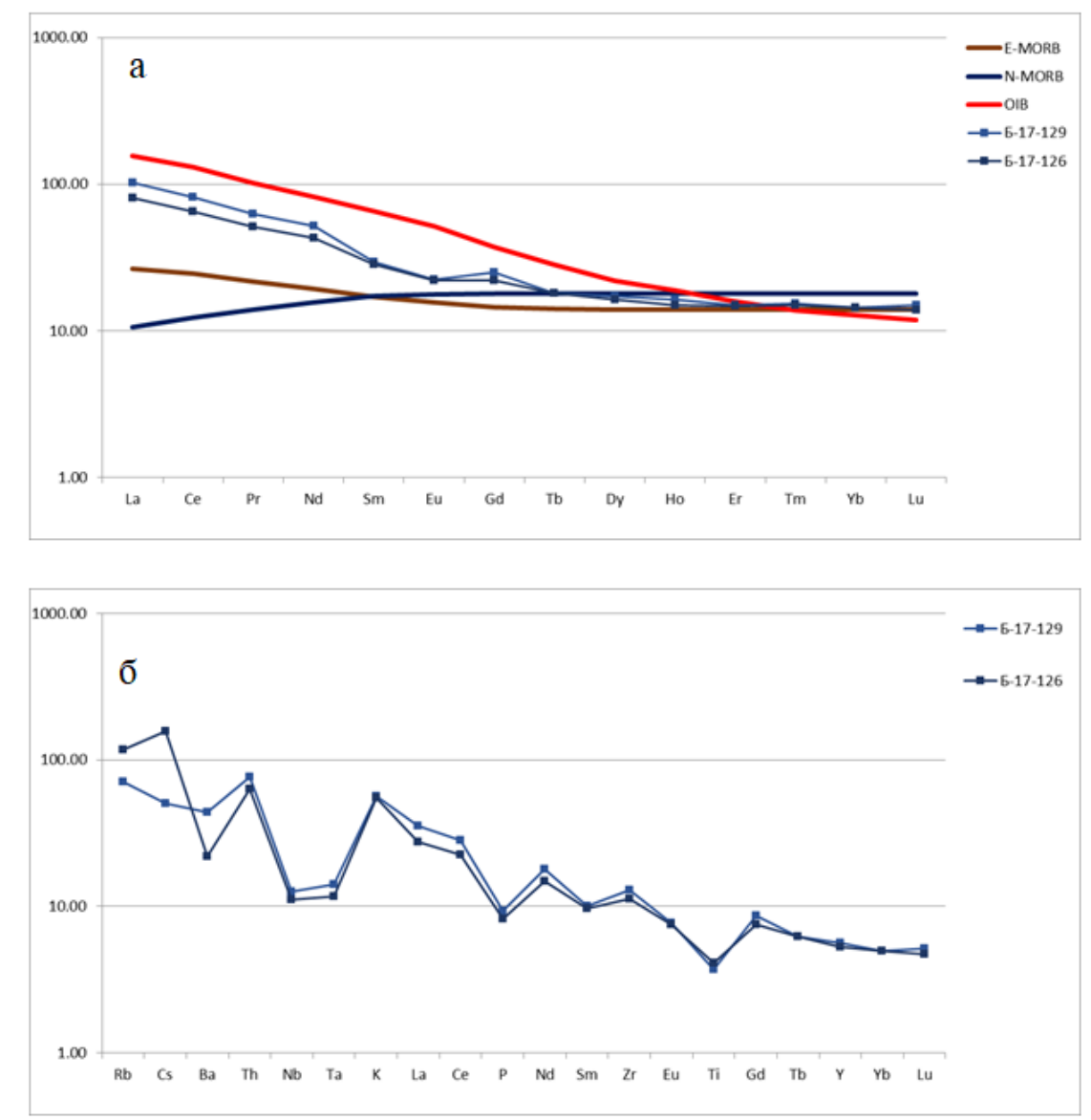

Рис. 8. Нормированные [12] по хондриту кривые распределения редкоземельных элементов (а) и нормированные по примитивной мантии мультиэлементные диаграммы редких элементов (б) для метатерригенных

\section{сланцев из Телецкой зоны}

В изученных породах одним из наиболее распространенных минералов является амфибол. Изучение амфиболов показало, что они зональные и по номенклатуре [13], со значениями $\mathrm{Na}_{\mathrm{B}}$ в среднем 0,1-0,2, относятся к кальциевым амфиболам. Составы центральных частей кристаллов по соотношению $(\mathrm{Na}+\mathrm{K}+\mathrm{Ca})$ - $(\mathrm{Al}+\mathrm{Fe})$ отвечают тремолитам и низкощелочным магнезиальным роговым обманкам, а краевых - высокощелочным роговым обманкам и паргаситам (рис. 9). 

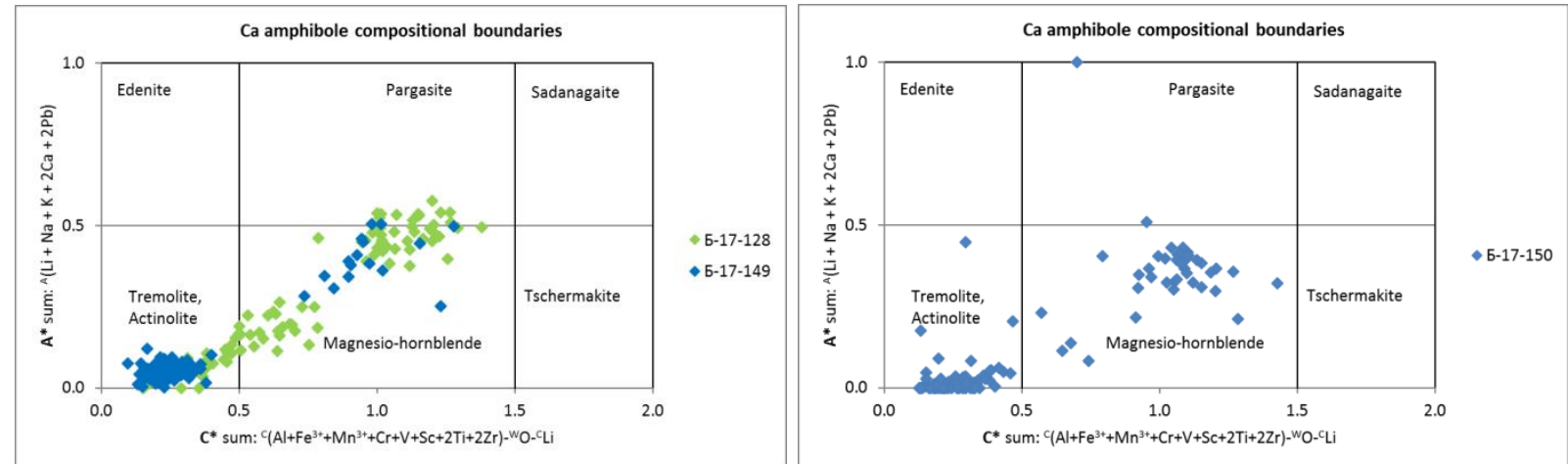

\section{Рис. 9. Диаграмма $A *-C *[14]$ с составами амфиболов из метабазальтов и метатерригенных сланцев Телецкой зоны Горного Алтая}

На рисунке «а» - зеленым цветом показаны составы амфиболов из образца метабазальта

№ Б-17-128, синим - из образца метатерригенного сланца

№ Б-17-149; на рисунке «б» - составы амфиболов из образца метатерригенного сланца № Б-17-150

Таким образом, результаты исследования позволяют рассматривать метатерригенные породы Телецкой зоны как продукты разрушения базальтандезибазальт-андезитовых пород. Наложенный на эти породы метаморфизм по уровню не превышает условий зеленосланцевых фаций, и его влияние на исходный состав пород незначительно. Исходя из этого, следует считать, что данные породы входят в состав аккреционного комплекса, в котором совмещены базальты океанической коры и турбидиты глубоководного желоба.

\section{Список литературы}

1. Кузнецов В.А. Тектоническое районирование и основные черты эндогенной металлогении Горного Алтая // Вопросы геологии и металлогении Горного Алтая - Новосибирск, ИГиГ СО АН СССР, - 1963. - С. 8-68.

2. Нехорошев В.П. Тектоника Алтая - Москва: Недра, - 1966. - 306 с.

3. Сурков В.С., Жеро О.Г., Уманцев Д.Ф., Зайцева Г.М. Тектоника и глубинное строение Алтае-Саянской складчатой области - Москва: Недра, 1973. - $144 \mathrm{c}$.

4. Буслов М.М., Синтубин М. Структурная эволюция Телецкой зоны Алтае-Саянской складчатой области // Геология и геофизика. - 1995. - Т. 36. № 10. - С. 91-98.

5. Смирнова Л.В. Структурно-кинематическая и метаморфическая эволюция Телецко-Башкаусской зоны сдвига в Телецком регионе (Горный 
Алтай) // Диссертация на соискание ученой степени кандидата геологоминералогических наук, $-2002 .-165$ с.

6. Буслов М.М., Ватанабе Т., Смирнова Л.В., Фудживара И., Ивата К., де Граве И., Семаков Н.Н., Травин А.В., Кирьянова А.П., Кох Д.А. Роль сдвигов в позднепалеозойско-раннемезозойской тектонике и геодинамике АлтаеСаянской и Восточно-Казахстанской складчатых областей // Геология и геофизика. -2003.

7. Dehandschutter B., Vysotsky E., Delvaux D., Klerkx J., Buslov M.M., Selesnev V.S., De Batist M. Structural evolution of the Teletsk graben (Russia Altai) // Tectonophysics. - № 351. - 2002. - P. 139-167.

8. Елкин Е. А., Сенников Н. В., Буслов М. М., Язиков А.Ю., Грацианова Р.Т., Бахарев Н.К. Палеогеографические реконструкции западной части Алтае-Саянской области в ордовике, силуре и девоне и их геодинамическая интерпретация // Геология и геофизика. -1994 . - № 7-8.

9. Смирнова Л.В., Тениссен К., Буслов М.М. Кинематика и динамика формирования позднепалеозойской структуры Телецкого региона (зона сочленения Горного Алтая и Западного Саяна) // Геология и геофизика. - 2002. - T. 43. - № 2. - C. 115-127.

10. Le Maitre R.W., Bateman P., Dudek A. A classification of igneous rocks and glossary of terms. Blackwell, Oxford, -1989.

11. Jensen L.S. A new cation plot for classifying subalkalic volcanic rocks // Ontario Div. Mines. Misc, $-1976 .-66$ p.

12. Sun S., McDonough W.F. Chemical and isotopic systematics of oceanic basalts: implications for mantle composition and processes // Geological Society of London, Special Publication, - 1989. - V. 42. - P. 313-345.

13. Leake B.E., Woolley A.R., Arps C.E. S., Birch W.D., Gilbert M.C., Grice J.D., Hawthorne F.C., Kato A., Kisch H.J., Krivovichev V.G, Linthout K., Laird J., Mandarino J., Maresch W.V., Nickel E.H., Rock N. M.S., Schumacher J.C., Smith D.C., Stephenson N.C.N., Ungaretti L., Whittaker E.J.W., Youzhi G. Nomenclature of amphiboles: Report of the Subcommittee on Amphiboles of the International Mineralogical Association Commission on New Minerals and Mineral Names // Mineralogical Magazine. April, - 1997. - V. 61. - P. 295-321.

14. Hawthorne F.C., Oberti R., Harlow G.E., Maresch W.V., Martin R.F., Schumacher J.C., Welch M.D. Nomenclature of the amphibole supergroup: IMA Report // American mineralogist. October, - 2012. - V. 97. - P. 2031-2048.

(C) В.Д. Зиндобрый, М.М. Буслов, 2022 512 